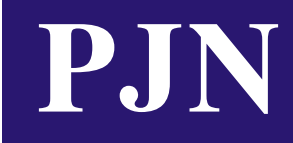

ISSN 1680-5194

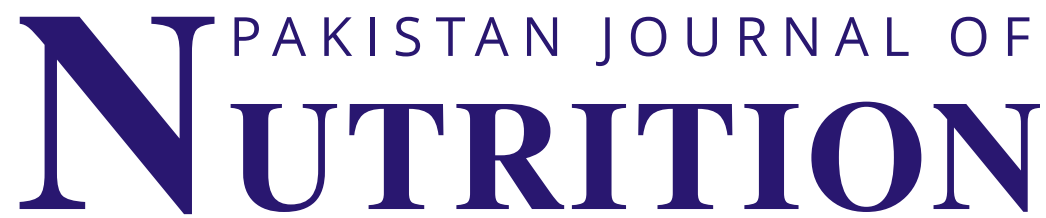

ANSI迫e佔

308 Lasani Town, Sargodha Road, Faisalabad - Pakistan Mob: +92 3003008585 , Fax: +92 418815544

E-mail: editorpjn@gmail.com 


\title{
Research Article Production of Extracellular $\beta$-mannanase by Bacillus
amyloliquefaciens on a Coconut Waste Substrate
}

\author{
${ }^{1}$ Zurmiati, ${ }^{1}$ Wizna, ${ }^{2}$ M. Hafil Abbas and ${ }^{1}$ Maria Endo Mahata \\ ${ }^{1}$ Department of Animal Feed and Nutrition, Faculty of Animal Husbandry, Andalas University, 25163 Padang, Indonesia \\ ${ }^{2}$ Department of Livestock Production, Faculty of Animal Husbandry, Andalas University, 25163 Padang, Indonesia
}

\section{Abstract}

Background and Objective: Mannanase is a decomposer of the compound mannan, which is produced by many microorganisms including bacteria. This enzyme can be utilized in various industrial processes, such as in the animal feed industry to increase the nutritional value of the feed. This study aims to optimize the production and function of the mannanase enzyme, which is produced by Bacillus amyloliquefaciens on a coconut waste substrate. Methodology: This study was designed in the form of laboratory experiments described herein and repeated 3 times. The substrate dose, incubation time, optimum pH and temperature of the mannanase enzyme were measured. Results: The results of this study showed that the best conditions were a substrate ratio of $80 \%$ coconut waste to $20 \%$ tofu waste, a $48 \mathrm{~h}$ incubation time, a pH of 6.5 and a temperature of $40^{\circ} \mathrm{C}$ yielding a mannanase enzymatic activity of $5.13 \mathrm{U} \mathrm{mL} \mathrm{L}^{-1}$. When locust bean gum was added to the substrate composed of coconut and tofu waste, the best conditions were a dose of $0.6 \%$, a $48 \mathrm{~h}$ incubation time, a pH $=6.5$ and a temperature of $40^{\circ} \mathrm{C}$ yielding a $5.92 \mathrm{U} \mathrm{mL}^{-1}$ mannanase enzymatic activity. Conclusion: It is concluded that the activity of the mannanase enzyme with the substrate composed of coconut and tofu waste is not much different from that with the substrate containing locust bean gum, with the difference being only $13.34 \%$.

Key words: Bacillus amyloliquefaciens, enzyme, $\beta$-mannanase, mannan, galactomannan

Citation: Zurmiati, Wizna, M. Hafil Abbas and Maria Endo Mahata, 2017. Production of extracellular $\beta$-mannanase by Bacillus amyloliquefaciens on a coconut waste substrate. Pak. J. Nutr., 16: 700-707.

Corresponding Author: Zurmiati, Department of Animal Feed and Nutrition, Faculty of Animal Husbandry, Andalas University, 25163 Padang, Indonesia Tel: +6285274200572

Copyright: @ 2017 Zurmiati et al. This is an open access article distributed under the terms of the creative commons attribution License, which permits unrestricted use, distribution and reproduction in any medium, provided the original author and source are credited.

Competing Interest: The authors have declared that no competing interest exists. 


\section{INTRODUCTION}

Hemicellulose is a complex polysaccharide that is abundant in the cell walls of higher plants. Mannan is the major hemicellulose in cell walls, endosperm and plant seeds'. Based on the sugar composition, hemicellulose can be distinguished as xylan, mannan, arabinogalactan or arabian. Mannan can be grouped into four subfamilies depending on the side chain structure: Mannan, glucomannan, galactomannan and galactoglucomannan². Mannan and heteromannan are widespread in nature as part of the hemicellulosic fraction and are found in plant cell walls. They can decrease the digestibility and use of nutrients as well as nutrient encapsulation and they can also increase the viscosity of feed in the gut, which ultimately reduces the rate of hydrolysis and nutrient absorption in rations. Hetero-1,4-D-xilan and hetero-1,4-D-mannan (galactose and glucomannan) are often used in various industrial processes ${ }^{3}$. The mannan compound is a polymer of mannose, while galactomannan is a galactose-intensive mannose polymer ${ }^{4}$. Mannan is particularly present in endosperm, copra, palm, coffee and locust beans ${ }^{5}$. Coconut waste is known to contain a high mannan content. Coconut waste contains polysaccharide components in the form of galactomannan $61 \%$, mannan $26 \%$ and cellulose $13 \%{ }^{6}$. Coconut waste is industrial waste or household waste that has the potential to be used as poultry feed because it is easily obtained from the remnants of the production of traditional virgin coconut oil (VCO). However, the utilization of coconut waste as livestock feed is still limited because of its high mannan content.

Mannan can be degraded by the mannanase enzyme. The mannanase enzyme is the enzyme that can decompose heteromannan into mannose, glucose and galactose. Mannan degradation requires a variety of enzymes such as $\beta$-mannanase (EC 3.2.178), which can hydrolyze $\beta-1,4-D$ mannopyranosyl in the main skeleton of mannan polymers such as galactomannan and glucomannan to produce short chain mannooligosaccharides. Furthermore, the compound is hydrolyzed by the action of the $\beta$-mannosidase enzyme (EC 3.2.1.25) and $\alpha$-galactosidase (EC 3.2.1.22), yielding 7 mannose and galactose molecules ${ }^{7}$. The mannanase enzyme can be produced by microorganisms commonly found in the ground, compost, or rumen animals ${ }^{3}$. Several Bacillus species that produce the mannanase enzyme are as follows: B. licheniformis ${ }^{8}$, Bacillus sp. strain JAMB- $750^{9}$, B. subtilis WY $34^{10}, B$. subtilis $B 36^{11}, B$. subtilis WL- $3^{12}, B$. circulans CGMCC1554 ${ }^{13}$, Bacillus sp. MSJ-514, B. licheniformis ${ }^{15}$, B. subtilis $\mathrm{BCC} 41051^{16}$, B. subtilis $\mathrm{Bs} 5^{17}$, B. subtilis $\mathrm{G} 1^{18}$, B. subtilis
MAFICS $11^{19}$, B. subtilis TJ $102^{20}$, B. nealsonii PN $11^{21}$, B. subtilis $\mathrm{YH} 12^{22}, B$. circulans NT $6.7^{23}, B$. amyloliquefaciens $10 \mathrm{~A} 1^{24}$ and $B$. amyloliquefaciens CS $47^{25}$.

Several studies regarding $\beta$-mannanase characterization have been published. Bacteria of B. circulans NT 6.7 produce the mannanase enzyme at an optimum $\mathrm{pH}$ and temperature of 6.0 and $60^{\circ} \mathrm{C}$, respectively ${ }^{23}$. B. subtilis MAFICS 11 produce the mannanase enzyme at an optimum $\mathrm{pH}$ and temperature of 6.0 and $5.0^{\circ} \mathrm{C}$, respectively ${ }^{19}$. Bacillus pumilus (M27) produce the mannanase enzyme at an optimum $\mathrm{pH}$ and temperature of 8 and $60^{\circ} \mathrm{C}$, respectively ${ }^{26}$. Bacillus sp., produce the mannanase enzyme at an optimum $\mathrm{pH}$ and temperature of 7.0 and $60^{\circ} \mathrm{C}^{27}$. Bacillus amyloliquefaciens bacteria isolated from Lunang Kab, Pesisir Selatan, West Sumatra, Indonesia, produce several types of enzymes and give a good effect on the ration efficiency of ducks and improve feed quality. The administration of B. amyloliquefaciens to the drinking water of starter Pitalah ducks for 6 weeks decreased feed consumption and improved the efficiency of the ration, with a> $15 \%$ decrease in feed conversion due to an increase in the small intestinal CFU and acidity. This, in turn, resulted in an increase in the income over feed cost (IOFC) but has no influence on weight gain ${ }^{28}$. The fermentation process of rice bran with $B$. amyloliquefaciens caused a change of nutrient content, the fermentation to increase digestibility of crude protein, calcium, phosphor, but does not decrease crude fiber ${ }^{29}$. However, characterization of the mannanase enzyme in B. amyloliquefaciens bacteria has never been performed. From the description above, study is conducted to discover the optimum conditions for the production of the mannanase enzyme by B. amyloliquefaciens.

\section{MATERIALS AND METHODS}

Organisms: The B. amyloliquefaciens bacteria were isolated from Lunang. Kab, Pesisir Selatan, West Sumatra, Indonesia.

\section{Determination of the best substrate ratio of coconut waste to the tofu waste, amount of locust bean gum and incubation time for $\beta$-mannanase production: To obtain the} maximum production of $\beta$-mannanase, a production curve was made. The first step to make a starter is to take $1 \mathrm{~g}$ of B. amyloliquefaciens cultures and inoculate it on $25 \mathrm{~mL}$ of nutrient broth medium. The culture was incubated at $40^{\circ} \mathrm{C}$ and $120 \mathrm{rpm}$ for $48 \mathrm{~h}$ and then, $4 \%$ starter is inoculated in the basic production medium [ $0.35 \%$ yeast extract, $0.35 \%$ tripton, $0.035 \% \mathrm{MgSO}_{4}, 0.245 \% \mathrm{KH}_{2} \mathrm{PO}_{4}, 0.175 \%\left(\mathrm{NH}_{4}\right)_{2} \mathrm{SO}_{4}$ and $0.2 \%$ $\mathrm{NaCl}$ ratio of the coconut waste to tofu waste according to the 
treatment, i.e., $90: 10,80: 20,70: 30$ and 60:40\%]. The dosage of locust bean gum as a substitute into the substrate of coconut waste and tofu waste varied according to the treatment $(0.4,0.5$ and $0.6 \%)$. The bacteria were incubated at $40^{\circ} \mathrm{C}$ and $120 \mathrm{rpm}$. Sampling is performed every $12 \mathrm{~h}$, starting from the 12th $\mathrm{h}$ until the 120th $\mathrm{h}$ and each treatment is repeated 3 times. Samples as much as $3 \mathrm{~mL}$ were taken to be tested for $\beta$-mannanase activity. The $\beta$-mannanase activity test utilized the Nelson method ${ }^{30}$.

\section{Determination of the best $\mathrm{pH}$ for the medium for the} production of $\beta$-mannanase: The determination of the $\mathrm{pH}$ of the medium for the optimum production of $\beta$-mannanase by $B$. amyloliquefaciens was performed by growing B. amyloliquefaciens in production medium with $\mathrm{pH}$ values of $2,2.5,3,3.5,4,4.5,5,5.5,6,6.5,7,7.5,8,8.5,9,9.5$ and 10 after incubation at $40^{\circ} \mathrm{C}$ for $48 \mathrm{~h}$ on a substrate with a ratio of coconut pulp to tofu waste of $80: 20 \%$ and the addition of $0.6 \%$ locust bean gum. The supernatant was then removed to test for its $\beta$-mannanase activity.

\section{Determination of the best temperature of the medium for} the production of $\beta$-mannanase: The determination of the medium temperature for the optimum production of $\beta$-mannanase by $B$. amyloliquefaciens was performed by growing $B$. amyloliquefaciens in production medium with temperatures of $20,25,30,35,40,45,50,55$ and $60^{\circ} \mathrm{C}$. After incubation at a pH of 6.5 for $48 \mathrm{~h}$ on a substrate with a ratio of coconut waste to tofu waste of $80: 20 \%$ and the addition of $0.6 \%$ locust bean gum, the supernatant was then removed to test for its $\beta$-mannanase activity.

Mannanase: To measure the mannanase activity using the method of Nelson ${ }^{30}$, the test for the activity of mannanase was carried out by taking $1 \mathrm{~mL}$ of crude enzyme and adding $1 \mathrm{~mL}$ of substrate $(0.5 \%$ locust bean gum in $0.01 \mathrm{M}$ phosphate buffer at a $\mathrm{pH}$ of 7) and then mixing them using a vortex mixer. They were then reacted in a shaker water bath (MEMMERT, Waterbath, Model WNB 14) for $30 \mathrm{~min}$ at $60^{\circ} \mathrm{C}$. Furthermore, the reaction is stopped by placing it in boiling water for $5 \mathrm{~min}$. Then, the hydrolyzed products were centrifuged (Hitachi himac CR21GIII) with a speed $5000 \mathrm{rpm}$ for $30 \mathrm{~min}$. Approximately $1 \mathrm{~mL}$ of hydrolysate was combined with Nelson $A B$ reagent $(1 \mathrm{~mL}$ ) and cooked in boiling water for $5 \mathrm{~min}$. Then, phosphomolybdate reagent $(1 \mathrm{~mL})$ and distilled water $(7 \mathrm{~mL})$ were added, followed by the release of glucose, which is read using a spectrophotometer (Shimadzu UV-1800 UV-vis spectrophotometer) at a wavelength of $575 \mathrm{~nm}$.
Experimental design: This study was designed in the form of the described laboratory experiments repeated 3 times. To obtain the optimum results and activity of the mannanase enzyme, the coconut waste is combined with the tofu waste in the following ratios: A. 90:10, B. $80: 20$, C. $70: 30$ and D. $60: 40 \%$. Then, locust bean gum in dosages of $0.6,0.5$ and $0.4 \%$ was added to the substrate.

\section{RESULTS AND DISCUSSION}

Influence of the incubation time, ratio of coconut waste to tofu waste and addition of locust bean gum as a growth substrate on the production of $\beta$-mannanase by B. amyloliquefaciens: The experiments were performed on substrates with the following ratios of coconut to tofu waste: $90: 10 \%, 80: 20 \%, 70: 30 \%$ and 60:40\%. Locust bean gum was added at concentrations of $0.4,0.5$ and $0.6 \%$. To determine the optimum conditions for $\beta$-mannanase production by B. amyloliquefaciens, incubation times of $12,24,36,48,60,72$, $84,96,108$ and $120 \mathrm{~h}$ were evaluated (Fig. 1, 2). The pH and temperature of the medium were 7.0 and $40^{\circ} \mathrm{C}$, respectively. The production of $\beta$-mannanase by $B$. amyloliquefaciens is expressed in units of enzyme activity because the concentration of the enzyme is directly proportional to the enzyme activity. At an incubation temperature of $40^{\circ} \mathrm{C}$, mannanase was produced by $B$. amyloliquefaciens starting at 12 th $h$, the activity continued to rise and the highest value was at $48 \mathrm{~h}$ with an activity of $2.24 \mathrm{U} \mathrm{mL}^{-1}$ on a substrate with a ratio of coconut pulp to tofu waste of $80: 20 \%$. The activity slowly decreased after $48 \mathrm{~h}$ until the 120th $\mathrm{h}$, which had an activity of $1.62 \mathrm{U} \mathrm{mL}^{-1}$ (Fig. 1). Likewise with locust bean gum added into the substrate, the enzyme activity continue to increase and was the highest at $48 \mathrm{~h}$, with the activity of $2.28 \mathrm{U} \mathrm{mL}^{-1}$ at a locust bean gum concentration of $0.6 \%$. Then, the activity slowly decreased until $120 \mathrm{~h}$, at which a value of

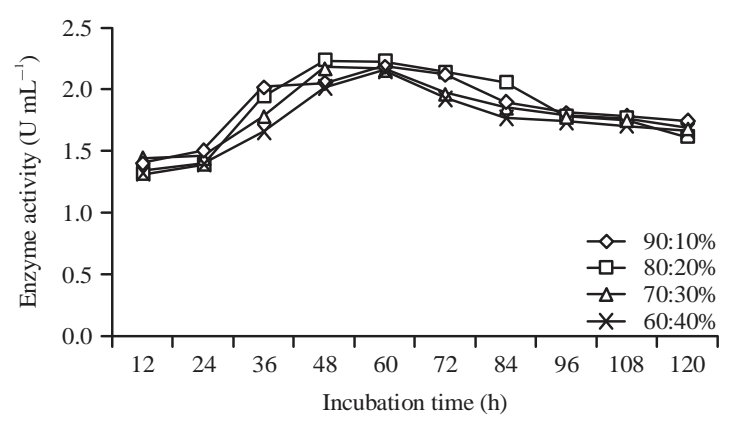

Fig. 1: Activity of the mannanase enzyme with various incubation times and ratios of coconut and tofu waste in the substrate 
$1.65 \mathrm{U} \mathrm{mL}^{-1}$ (Fig. 2) was reached. This is caused by the amount of component on the substrate as the incubation time increases along with the growth of bacterial cells, which then decreases when the required carbon source is low. Figure 1 and 2 show that once the enzyme activity reaches its optimum point at $48 \mathrm{~h}$, there is a decrease in the enzyme activity. The results of this study are not much different from those

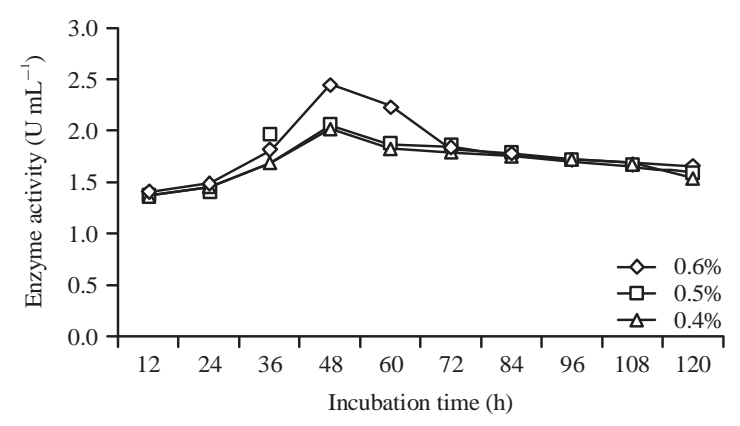

Fig. 2: Activity of the mannanase enzyme for various incubation times and with various amounts of locust bean gum added to the substrate reported by Sumardi ${ }^{31}$, in which the best conditions for the thermophilic aerobic bacteria Geobacillus stearothermophilus $\mathrm{L}-07$ to produce $\beta-1,4$-mannanase $\left(3.1 \mathrm{U} \mathrm{mg}^{-1}\right)$ were found to be with a carbon source of $0.65 \%(\mathrm{w} / \mathrm{v})$ locust bean gum, at a $\mathrm{pH}$ of 7.0 and with $36 \mathrm{~h}$ of incubation at $60^{\circ} \mathrm{C}$. Additionally, the same treatment but with the temperature increased to $70^{\circ} \mathrm{C}$ led to the best production with incubation for $12 \mathrm{~h}$ $\left(3.2 \mathrm{U} \mathrm{mg}^{-1}\right)$.

Production of $\beta$-mannanase in medium with various $\mathbf{p H}$ values: The effect of the $\mathrm{pH}$ on mannanase production is presented in Fig. 3 and 4. Treatment to change the medium $\mathrm{pH}$ to produce $\beta$-mannanase $B$. amyloliquefaciens was performed on the substrate of coconut waste and tofu waste with a ratio of $80: 20 \%$, with the addition of $0.6 \%(\mathrm{w} / \mathrm{v})$ locust bean gum and after $48 \mathrm{~h}$ of incubation time. From the experimental results, it is known that $\beta$-mannanase is produced by $B$. amyloliquefaciens at $\mathrm{pH}$ values from 2-10. At a $\mathrm{pH}$ of 2.0 and 10 with a substrate having a ratio of coconut waste to tofu waste of $80: 20 \%$, the $\beta$-mannanase production is very small $\left(0.91\right.$ and $\left.0.86 \mathrm{U} \mathrm{mL}^{-1}\right)$ (Fig. 3).

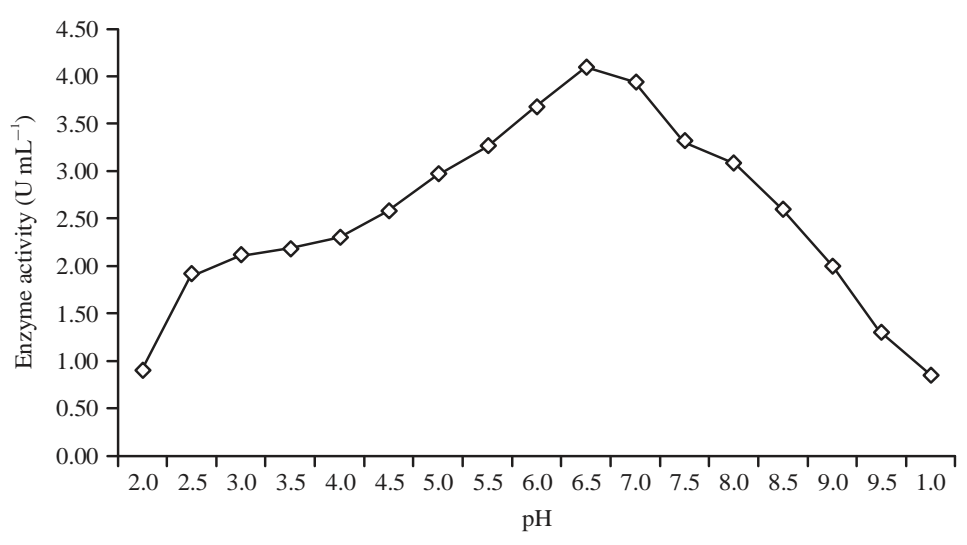

Fig. 3: Activity of the mannanase enzyme at various $\mathrm{pH}$ values with a substrate of coconut and tofu waste (80:20\%)

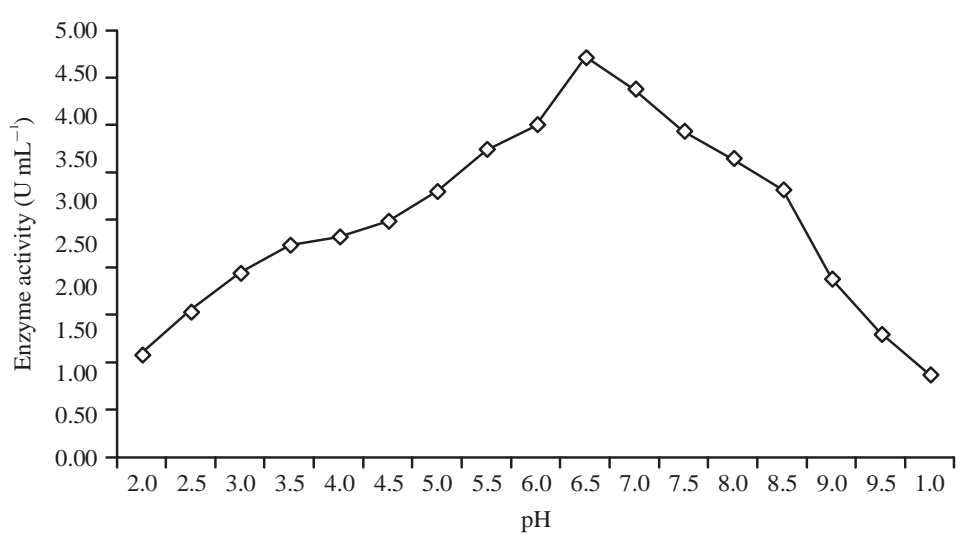

Fig. 4: Activity of the mannanase enzyme at various $\mathrm{pH}$ values with $0.6 \%$ locust beam gum added to the substrate 


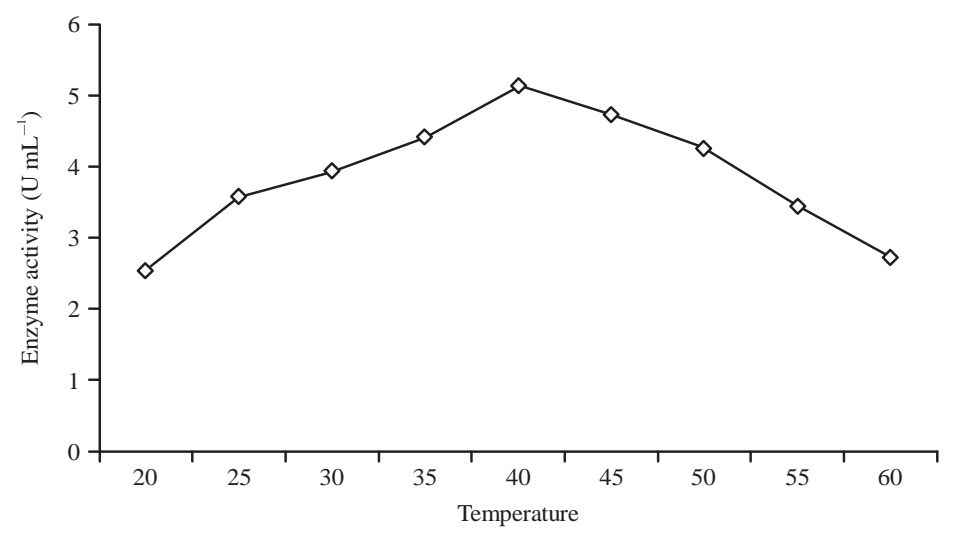

Fig. 5: Activity of the mannanase enzyme for various temperatures with a substrate of coconut and tofu waste (80:20\%)

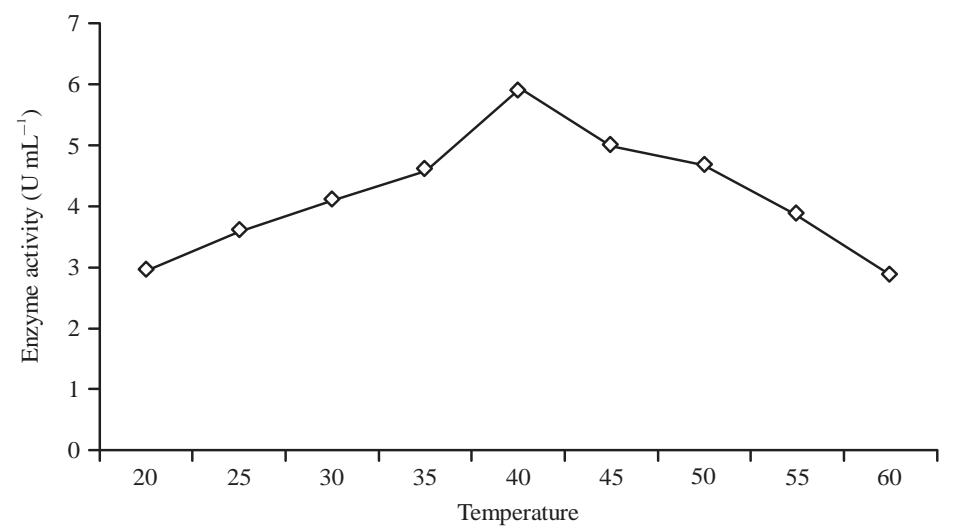

Fig. 6: Activity of the mannanase enzyme for various temperatures with $0.6 \%$ locust beam gum added to the substrate

Likewise with $0.6 \%(\mathrm{w} / \mathrm{v})$ locust bean gum added, the enzyme activities were 1.22 and $0.99 \mathrm{U} \mathrm{mL}^{-1}$, respectively (Fig. 4). From the treatment to evaluate the effect of the $\mathrm{pH}$ of the medium with a substrate having a ratio of coconut waste to tofu waste of $80: 20 \%$, it is known that the optimum pH for growth is obtained at $6.5\left(4.09 \mathrm{U} \mathrm{mL}^{-1}\right)$ (Fig. 3). Likewise, with a substrate having $0.6 \%(\mathrm{w} / \mathrm{v})$ locust bean gum added, it is known that the optimum $\mathrm{pH}$ for growth is 6.5 (4.71 $\mathrm{U} \mathrm{mL}^{-1}$ ) (Fig. 4). At pH values lower or higher than the optimum $\mathrm{pH}$, mannanase production decreases. This is closely related to bacterial growth. At acidic or alkaline $\mathrm{pH}$, bacterial growth will be inhibited due to the elucidation of $\mathrm{H}^{+}$and $\mathrm{H}^{-}$ions, decreased cellular stability, cell membrane enzyme inhibition and protein transport ${ }^{32}$.

The optimal $\mathrm{pH}$ value obtained in this study for mannanase production by B. amyloliquefaciens was similar to that for mannanase production by Bacillus subtilis $\mathrm{YH} 12$, with optimum conditions of a $\mathrm{pH}$ of 6.5 and $55^{\circ} \mathrm{C}^{22}$. Bacillus amyloliquefaciens $\mathrm{CS} 47$ produces the mannanase enzyme at a pH of 6.0 and $50^{\circ} \mathrm{C}^{25}$. The optimum of $\mathrm{pH}$ and temperature for the activity of the mannanase enzyme produced by Bacillus sp., SWU 60 are 6.0 and $60^{\circ} \mathrm{C}$, respectively ${ }^{33}$. In general, the optimum pH of mannanase is between 7.1 and 7.7, except for the Bacillus originating mannanase, whose optimum $\mathrm{pH}$ range is $3-6 \cdot 5^{7}$. Each enzyme has an optimum $\mathrm{pH}$ and is active in a relatively narrow $\mathrm{pH}$ range ${ }^{34}$ because each enzyme has an optimum $\mathrm{pH}$ typical for its enzyme application and thus, it will also be efficient at that $\mathrm{pH}^{4}$.

Production of $\beta$-mannanase at various temperatures: Treatment to evaluate the effect of temperature on the production of $\beta$-mannanase by $B$. amyloliquefaciens was performed on the substrate with a ratio of coconut waste to tofu waste of $80: 20 \%$ with the addition of $0.6 \%(\mathrm{w} / \mathrm{v})$ locust bean gum, with an incubation time of $48 \mathrm{~h}$ and at a pH of 6.5 . The effect of temperature on the production of the mannanase enzyme by $B$. amyloliquefaciens can be seen in (Fig. 5, 6). From the experiment results, it is known that B. amyloliquefaciens produced $\beta$-mannanase in a temperature range of $20-60^{\circ} \mathrm{C}$. In the temperature range of 
20-60 ${ }^{\circ}$, the production of $\beta$-mannanase on the substrate with a ratio of coconut waste to tofu waste of $80: 20 \%$, was very small ( 2.53 and $2.68 \mathrm{U} \mathrm{mL}^{-1}$ ) (Fig. 5). The production of $\beta$-mannanase with the addition of $0.6 \%(\mathrm{w} / \mathrm{v})$ locust bean gum to the substrate is also very small $\left(2.96\right.$ and $2.86 \mathrm{U} \mathrm{mL}^{-1}$ ) (Fig. 6). The enzyme activity will increase with an increase of the temperature until the optimum temperature is reached. However, after passing the optimum temperature, the enzyme activity will decrease. Increased temperatures will increase the kinetic energy of the enzymes so that the vibrational and rotational movement of the enzymes and substrates will be increase, which will cause greater opportunities to collide. There is an increase in temperature up to a certain limit that will cause increased catalytic activity of the enzyme and increased the process of enzyme destruction ${ }^{34}$. From the effect of the media temperature on a substrate with a ratio of coconut to tofu waste of $80: 20 \%$, it is known that the optimum medium growth temperature is $40^{\circ} \mathrm{C}\left(5.13 \mathrm{U} \mathrm{mL}^{-1}\right)$ (Fig. 5). With $0.6 \%(\mathrm{w} / \mathrm{v}$ ) locust bean gum added to the substrate, it is known that the optimum temperature of growth is obtained at a medium temperature of $40^{\circ} \mathrm{C}\left(5.92 \mathrm{U} \mathrm{mL}^{-1}\right)$ (Fig. 6).

The production of mannanase decreases at a temperature higher than the optimum temperature. This is due to the increase of the melting point of the fat layer and the depletion of the cell membrane (leak) as well as the occurrence of protein denaturation that is sensitive to heat, thus, the growth of bacteria is inhibited and the production of the enzyme decreases. The cell membrane adjusts the composition of saturated fatty acids according to changes in the ambient temperature ${ }^{35}$. The results of this study are not much different from those reported by Kanjanavas et $a /{ }^{36}$, in which B. licheniformis THCM 3.1 produces the mannanase enzyme at an optimum temperature and $\mathrm{pH}$ of $45^{\circ} \mathrm{C}$ and 9.0, respectively. Bacillus amyloliquefaciens $10 \mathrm{~A} 1$ with an ammonium nitrate nitrogen source produced a mannanase enzyme activity of $61.5 \mathrm{U} \mathrm{mg}^{-1}$ at a temperature of $30^{\circ} \mathrm{C}$ and $\mathrm{pH}$ of $7^{24}$. The best conditions for producing $\beta$-1,4-mannanase (3.1 $\mathrm{U} \mathrm{mg}^{-1}$ ) by the bacteria of the thermophilic aerobic Geobacillus stearothermophilus $\mathrm{L} 07$ were with a carbon source of $0.65 \%$ (w/v) locust bean gum, a pH of 7.0 and $36 \mathrm{~h}$ of incubation time at $60^{\circ} \mathrm{C}$. The same treatment but with the temperature increased to $70^{\circ} \mathrm{C}$ were the best conditions for incubation for $12 \mathrm{~h}\left(3.2 \mathrm{U} \mathrm{mg}^{-1}\right)^{31}$. Based on the results of this experiment, it can be seen that a substrate with a composition of $80 \%$ coconut waste and $20 \%$ tofu waste with the addition of $0.6 \%$ locust bean gum is better than the other treatments because it produces the highest mannanase activity. The mannanase enzyme produced by Bacillus amyloliquefaciens can be applied well at a pH of 6.5 and a temperature of $40^{\circ} \mathrm{C}$, but at lower and higher $\mathrm{pH}$ values or higher temperatures, the ability to produce the mannanase enzyme will not be optimal.

\section{CONCLUSION}

Bacteria of $B$. amyloliquefaciens produce the mannanase enzyme and the activity of the mannanase enzyme with a substrate that is a combination of coconut and tofu waste is not much different compared to with a substrate using locust bean gum, with only a $13.34 \%$ difference and the optimum $\mathrm{pH}$ and temperature are the same.

\section{SIGNIFICANCE STATEMENTS}

This study discovers the optimum conditions for the production of the mannanase enzyme by Bacillus amyloliquefaciens bacteria, which can be beneficial for the livestock industry to improve the nutritional value of feed ingredients. This study will help researchers to uncover the ability of Bacillus amyloliquefaciens to produce a mannanase enzyme that can be explored by other researchers. Thus, a new theory on the optimum conditions for Bacillus amyloliquefaciens to produce the mannanase enzyme may be arrived at.

\section{ACKNOWLEDGMENTS}

This study was supported by a National Strategic Research Grant from the Directorate General of Higher Education, Department of National Education, Republic of Indonesia grant program (124/SP2H/LT/DRPM/III/-2015). Authors are very grateful to the Minister of Research Technology and Higher Education who allowed us to conduct this study.

\section{REFERENCES}

1. Petkowicz, C.L.D.O., F. Reicher, H. Chanzy, F.R. Taravel and R. Vuong, 2001. Linear mannan in the endosperm of Schizolobium amazonicum. Carbohydr. Polym., 44: 107-112.

2. Moreira, L.R. and E.X. Filho, 2008. An overview of mannan structure and mannan-degrading enzyme systems. Applied Microbiol. Biotechnol., 79: 165-178.

3. Hilge, M., S.M. Gloor, W. Rypniewski, O. Sauer and T.D. Heightman et al., 1998. High-resolution native and complex structures of thermostable $\beta$-mannanase from Thermomonospora fusca-substrate specificity in glycosyl hydrolase family 5 . Structure, 6: 1433-1444. 
4. Lehninger, A., 1994. Biochemical Basics I. (Thenawidjaja M., Translator). Penerbit Erlangga, Jakarta.

5. Ooi, T. and D. Kikuchi, 1995. Purification and some properties of $\beta$-mannanase from Bacillus sp. World J. Microbiol. Biotechnol., 11: 310-314.

6. Purawisastra, S., 2001. Effect of coconut galactomannan isolate on decreased serum cholesterol level of rabbit. Warta Litbang Kesehatan, Vol. 5, No. 3-4.

7. Duffaud, G.D., C.M. McCutchen, P. Leduc, K.N. Parker and R.M. Kelly, 1997. Purification and characterization of extremely thermostable beta-mannanase, beta-mannosidase and alpha-galactosidase from the hyperthermophilic eubacterium Thermotoga neapolitana 5068. Applied Environ. Microbiol., 63: 169-177.

8. Zhang, J., Z. He and K. Hu, 2000. Purification and characterization of $\beta$-mannanase from Bacillus licheniformis for industrial use. Biotechnol. Lett., 22: 1375-1378.

9. Takeda, N., K. Hirasawa, K. Uchimura, Y. Nogi and Y. Hatada et al., 2004. Purification and enzymatic properties of a highly alkaline mannanase from alkaliphilic Bacillus sp. strain JAMB-750. Int. J. Biol. Macromol., 4: 67-74.

10. Jiang, Z.Q., Y. Wei, D. Li, L. Li, P. Chai and I. Kusakake, 2006. High-level production, purification and characterization of a thermostable $\beta$-mannanase from the newly isolated Bacillus subtilis WY34. Carbohydr. Polym., 66: 88-96.

11. Li, Y.N., K. Meng, Y.R. Wang and B. Yao, 2006. A ß-mannanase from Bacillus subtilis B36: Purification, properties, sequencing, gene cloning and expression in Escherichia coli. Zeitschrift fur Naturforschung C, 61: 840-846.

12. Yoon, K.H., S. Chung and B.L. Lim, 2008. Characterization of the Bacillus subtilis WL-3 mannanase from a recombinant Escherichia coli. J. Microbiol., 46: 344-349.

13. Yang, P., Y. Li, Y. Wang, K. Meng and H. Luo et al., 2009. A novel $\beta$-mannanase with high specific activity from Bacillus circulans CGMCC1554: Gene cloning, expression and enzymatic characterization. Applied Biochem. Biotechnol., 159: 85-94.

14. Zhang, M., X.L. Chen, Z.H. Zhang, C.Y. Sun and L.L. Chen et al., 2009. Purification and functional characterization of endo- $\beta$-mannanase MAN5 and its application in oligosaccharide production from konjac flour. Applied Microbiol. Biotechnol., 83: 865-873.

15. Songsiriritthigul, C., B. Buranabanyat, D. Haltrich and M. Yamabhai, 2010. Efficient recombinant expression and secretion of a thermostable GH26 mannan endo-1,4- $\beta$-mannosidase from Bacillus licheniformis in Escherichia coli. Microb. Cell Factories, Vol. 9. 10.1186/14752859-9-20.
16. Summpunn, P., S. Chaijan, D. Isarangkul, S. Wiyakrutta and V. Meevootisom, 2011. Characterization, gene cloning and heterologous expression of $\beta$-mannanase from a thermophilic Bacillus subtilis. J. Microbiol., 49: 86-93.

17. Huang, J.L., L.X. Bao, H.Y. Zou, S.G. Che and G.X. Wang, 2012. High-level production of a cold-active B-mannanase from Bacillus subtilisBS5 and its molecular cloning and expression. Mol. Gen. Microbiol. Virol., 27: 14-17.

18. Vu, T.T., D.T. Quyen, T.T. Dao and S.T. Nguyen, 2012. Cloning, high-level expression, purification and properties of a novel endo-beta-1,4-mannanase from Bacillus subtilis G1 in Pichia pastoris. J. Microbiol. Biotechnol., 22: 331-338.

19. Lv, J., Y. Chen, H. Pei, W. Yang, Z. Li, B. Dong and Y. Cao, 2013. Cloning, expression and characterization of $\beta$-mannanase from Bacillus subtilis MAFIC-S11 in Pichia pastoris. Applied Biochem. Biotechnol., 169: 2326-2340.

20. Wang, M., S. You, S. Zhang, W. Qi and Z. Liu et al., 2013. Purification, characterization and production of $\beta$-mannanase from Bacillus subtilis TJ-102 and its application in gluco-mannooligosaccharides preparation. Eur. Food Res. Technol., 237: 399-408.

21. Chauhan, P.S., A. Bharadwaj, N. Puri and N. Gupta, 2014. Optimization of medium composition for alkali-thermostable mannanase production by Bacillus nealsonii $\mathrm{PN}-11$ in submerged fermentation. Int. J. Curr. Microbiol. Applied Sci., 3: 1033-1045.

22. Liu, H.X., J.S. Gong, H. Li, Z.M. Lu and H. Li et al., 2015. Biochemical characterization and cloning of an endo-1,4- $\beta$-mannanase from Bacillus subtilis $\mathrm{YH} 12$ with unusually broad substrate profile. Process Biochem., 50: 712-721.

23. Pangsri, P., Y. Piwpankaew, A. Ingkakul, S. Nitisinprasert and S. Keawsompong, 2015. Characterization of mannanase from Bacillus circulans NT6.7 and its application in mannooligosaccharides preparation as prebiotic. SpringerPlus, Vol. 4. 10.1186/s40064-015-1565-7.

24. Mabrouk, M.E.M. and A.M.D. El Ahwany, 2008. Production of 946-mannanase by Bacillus amylolequifaciens 10A1 cultured on potato peels. Afr. J. Biotechnol., 7: 1123-1128.

25. Cho, S.J., 2009. Isolation and characterization of mannanase producing Bacillus amyloliquefaciens CS47 from horse feces. J. Live Sci., 19: 1724-1730.

26. Adiguzel, A., H. Nadaroglu and G. Adiguzel, 2015. Purification and characterization of $\beta$-mannanase from Bacillus pumilus (M27) and its applications in some fruit juices. J. Food Sci. Technol., 52: 5292-5298.

27. Harnentis, Y. Marlida, Y. Rizal and M.E. Mahata, 2013. Isolation, characterization and production of mannanase from thermophilic bacteria to increase the feed quality. Pak. J. Nutr., 12: 360-364. 
28. Zurmiati, Wizna, M.H. Abbas, M.E. Mahata and R. Fauzano, 2017. Effect of Bacillus amyloliquefaciens as a probiotic on growth performance parameters of Pitalah ducks. Int. J. Poult. Sci., 16: 147-153.

29. Wizna, H. Abbas, Y. Rizal, A. Djulardi and H. Muis, 2012. The effect of supplementation of micro nutrient on nutrient rice bran which fermented by Bacillus amyloliquefaciens. Pak. J. Nutr., 11: 439-443.

30. Nelson, N., 1944. A photometric adaptation of the Somogyi method for the determination of glucose. J. Biol. Chem., 153: 375-380.

31. Sumardi, 2005. Isolation, characterization and extracellular $\beta$-mannanase production from Geobacillus stearothermophillus L-07. Dissertation. IPB., Bogor.

32. Booth, I.R., 1985. Regulation of cytoplasmic pH in bacteria. Microbiol. Rev., 49: 359-378.
33. Seesom, W., P. Thongket, T. Yamamoto, S. Takenaka, T. Sakamoto and W. Sukhumsirichart, 2017. Purification, characterization and overexpression of an endo-1,4- $\beta$-mannanase from thermotolerant Bacillus sp. SWU60. World J. Microbiol. Biotechnol., Vol. 33. 10.1007/s11274-017-2224-7.

34. Palmer, T., 1991. Understanding Enzymes. Ellis Horowood Ltd., England.

35. Ulusu, N.N. and E.F. Tezcan, 2001. Cold shock proteins. Turk. J. Med. Sci., 31: 283-290.

36. Kanjanavas, P., P. Khawsak, A. Pakpitcharoen, S. Areekit and T. Sriyaphai et al., 2009. Over-expression and characterization of the alkalophilic, organic solvent-tolerant and thermotolerant endo-1,4- $\beta$-mannanase from Bacillus licheniformis isolate THCM 3.1. ScienceAsia, 35: 14-23. 